\title{
Primitivismo e ciência do bomem no século XVIII
}

HÊLẼNE CLASTRES

Ao longo da série de estudos que consagrou à etnografia, à sua história e suas lacunas, Van Gennep nota o quanto foi tardio, comparado ao das outras ciências, o aparecimento das ciências humanas, da etnografia em particular, e a dificuldade que esta teve para se impor: dificuldade, diz ele, imputável em grande parte à própria etnografia, à flutuação de suas noçðes e de suas teorias. ${ }^{1}$ Daí, sem dúvida, essa reflexão que o reconduz ao passado: ao século XVIII e aos precursores do que ele chama de "etnografia teórica".

Gostaríamos de destacar duas questðes que atravessam seu estudo, pois elas, em muito, nos serviram de fio condutor. Desde o início, apresentando as obras de Démeunier, de Lafitau, de De Brosses, Van Gennep constata o isolamento, a independência de cada uma delas e, em cada caso, se interroga sobre esta descontinuidade. Por que, pergunta ele por exemplo, um Lafitau (que teve, entre outros méritos, o de ser o primeiro a definir, e de uma maneira tão precisa, em que consiste o método comparativo e dentro de que limites é possível aplicá-1o) permaneceu sem posteridade? E até mesmo ignorado por seu século? E, com efeito, natural o espanto, tratando-se de um século que

(1) A. Van Gennep. Religions, Moeurs et Légendes, Paris, Mercure de France, 1914. Em particular, na quinta série, o Cap. I: "algumas lacunas da etnografia atual"; e toda a segunda parte: "O método etnográfico na França no século XVIII". As citaçð̌es que se seguem são todas extraídas desses ensaios. 
quis fundar a ciência do Homem. De fato, não somente nenhum desses etnógrafos foi retomado pelos teóricos da época, como não há sequer laços de sucessão entre eles. Ao lê-los, pode-se ter, muito ao contrário, a impressão de repetição de uma mesma obra (com a diferença, é claro, dos povos estudados) já de início concluída, ou de antemão limitada e impossível de aperfeiçoar, que teria sido produzida de maneira intermitente: pois os projetos são idênticos, ${ }^{2}$ como os métodos, os modelos explicativos... e mesmo a forma da exposição ou as qualidades literárias. O traço mais marcante da etnografia teórica do século XVIII, se é possível caracterizá-la por um traço, é talvez uma certa solução de continuidade e, pode-se dizer, uma certa inércia: como se não houvesse história propriamente dita, ou como se ela não fosse cumulativa (podemos perfeitamente reduzir os intervalos, adicionando outras obras etnográficas àquelas que Van Gennep toma, sem modificar em nada essa característica). O exato oposto, conseqüentemente, do que vai caracterizar a etnologia um século depois, a saber, o "estado de flutuação" do qual se queixa Van Gennep, as noçðes que tiveram de ser continuamente "desfeitas e reconstruídas": enfim, tudo o que marca os começos da ciência e é indício de seu progresso.

A segunda pergunta de Van Gennep remete à interrupção que se produziu no começo do século XIX: “... no concernente às Ciências do Homem, houve uma interrupção, marcada pela morte da Sociedade dos Observadores do Homem". Ele vê ao menos uma razão desta interrupção na conjuntura histórica: "O limite 'século XIX' não tem nada de artificial, já que a Revolução e o Império marcam nitidamente uma interrupção temporária da produção intelectual, não somente literária mas também científica". E precisa ainda que, se a etnologia apareceu tardiamente na classe das disciplinas universitárias, é por causa da "recrudescência religiosa dos primeiros três quartos do século XIX". A interrupção e a retomąda tardia da etnologia seriam conseqüentemente imputáveis a causas exteriores a esta ciência mesma parcialmente imputáveis, em todo o caso, pois, por algumas observações, Van Gennep sugere que é necessário procurar outras causas, de tal forma que sua questão continua em aberto.

(2) Os títulos de suas obras são sugestivos a este respeito. Relembremos Lafitau: Moeurs des Sauvages Amériquains, comparées aux moeurs des Premiers Temps, 1724; De Brosses: Du culte des dieux fétiches, ou parallèle de l'ancienne religion de l'Egypte avec la religion actuelle de la Nigritie, 1760; Démeunier: L'esprit des usages et des coutumes des différens peuples, ou observations tirées des voyageurs et des historiens, 1776. 
É tanto em direção da história e da busca das razð̃es conjunturais, quanto em direção da epistemologia e da busca das razð̃es internas, que nos vemos orientados. As duas questðes, efetivamente (o porquê do caráter isolado das obras dos que foram chamados e, não sem razão, de "precursores", e o porquê dessa súbita interrupção) contêm uma terceira, subentendida, e que poderia, ingenuamente, ser assim enunciada: como é possível que a etnologia não tenha nascido no século XVIII quando, aparentemente, as condiçðes estavam reunidas para torná-la possível? Pois, que sentido tem falar de "precursores", em se surpreender com o caráter descontínuo das obras que fazem a "pré-história" da ciência? Em outras palavras, o que a história da etnologia indica quando (não pensando, aqui, somente em Van Gennep, mas também em Lowie, Métraux ou outros) estabelece, no interior do que ela reivindica como seu próprio passado, uma diferença entre seu verdadeiro começo (por volta do fim do século XIX) e seus pródromos mais ou menos esporádicos? Se se admite que a divisão é legítima - e não há razão para não considerá-la assim - pode-se perguntar o que a fundamenta. E esta questão remete, não à história cronológica das obras e das teorias, mas à história lógica de suas condiçð̃es de possibilidade: tais condiçðes estavam efetivamente presentes no século XVIII? Ou, mais exatamente (já que se sabe perfeitamente que a etnologia só apareceu mais tarde), que obstáculo, interno ao discurso antropológico de então, impossibilitava seu aparecimento?

$\hat{E}$ preciso esclarecer que o período que nos interessa (dado que, para nós, parece revelar uma unidade própria) vai do início do século, com a publicação das primeiras Lettres Edifiantes et Curieuses... dos Jesuítas (em 1702) e a dos Dialogues de La Hontan (1703), até o fim da Sociedade dos Observadores do Homem. Concordamos, pois, com Van Gennep neste ponto. E ainda estamos de acordo com ele quando precisa que apenas pertencem ao território da etnologia os "fenômenos de começo, e não os fenômenos muito evoluídos", e define o objetivo desta ciência como "estudar o homem semicivilizado e as populaçס̃es rurais da Europa": a etnologia emprega hoje outros termos, mas mantém essas distinçðes. Deixaremos de lado a etnologia rural, cuja história não coincide com a da etnologia dos povos primitivos, ou, como se falava ainda no século XVIII, dos povos selvagens.

$$
* * *
$$

No entanto, é uma inovação desse século o pensar os povos selvagens precisamente como povos primitivos. Primitivos, isto é, pri- 
meiros: no começo de uma história que é a do gênero humano. Pensamento ele mesmo novo, esta idéia da humanidade como "espécie", portanto dotada de uma unidade natural e tendente por natureza à mesma evolução (pois a Natureza fez o homem perfectível, ao contrário das outras espécies). "Originariamente", escreve Buffon, "só houve uma espécie de homens que, tendo-se multiplicado e disseminado por toda a terra, sofreu diferentes mudanças por influência do clima, pela diferença da alimentação, da maneira de viver, das doenças epidêmicas, e também pela mistura variada ao infinito de indivíduos mais ou menos semelhantes". ${ }^{3}$ Pouco importa, aqui, que a hipótese da unidade da espécie humana não tenha obtido unanimidade, e que alguns pensadores, Voltaire por exemplo, a tenham violentamente criticado. Permanece a novidade de uma teoria do homem, científica e não mais religiosa ou metafísica (como nos séculos precedentes), e que vai transformar radicalmente (quer se esteja ou não de acordo com Buffon) o modo de pensar a diversidade das sociedades. As duas idéias, a de um estado primeiro do homem e a de uma história natural da espécie, são correlatas e implicam uma terceira: que este estado primitivo é um estado de natureza. Voltaremos a essa última noção, cujo conteúdo não deixa de ser ambíguo.

Notemos, por enquanto, que é no seio das teorias dos naturalistas que são formulados postulados, hipóteses e conceitos sobre os quais vai se fundar todo o discurso antropológico do século XVIII. E que o naturalismo vai tentar explicar não somente a diversidade física, mas também a dos "naturais" - dos caracteres, diríamos nós - e, mais ainda, dos costumes. Assim Buffon confere, a uma história natural da espécie, a tarefa de dar conta das variedades que se podem constatar entre os homens dos "diferentes climas": "A primeira e a mais marcante dessas variedades é a da cor, a segunda é a da forma e do tamanho, e a terceira é a do natural dos diferentes povos". Dos traços físicos vamos, então, gradualmente, para os traços morais e intelectuais. A natureza não dá saltos, a ciência tampouco. "Ainda que os negros tenham pouco espírito, não deixam de ter muito sentimento, são alegres ou melancólicos, laboriosos ou preguiçosos, amigos ou inimigos segundo a maneira pela qual são tratados... Eles têm pois... o coração excelente, possuem o germe de todas as virtudes". Para não sermos injustos com Buffon, acrescentemos que este retrato ingenuamente condescendente era, no seu tempo, banalidade muito difundida, que não impediu Buffon de tomar vivamente partido contra a escravidão.

(3) Buffon, "Histoire Naturelle de l'Homme", in Buffon, éd. Jean Piveteau, PUF, 1954, p. 315. 
Como o universo, o homem é cognoscível através de leis: pode e deve ser objeto de ciência. Um encaminhamento metódico: do simples ao complexo (do físico ao moral e ao mental), e do particular ao geral (do indivíduo às relaçðes sociais); um pequeno número de princípios bem fundamentados, dentre os quais, aquele, herdado de Locke: as idéias provêm dos sentidos, donde segue que, colocados em condiçð̃es idênticas, os homens recebem as mesmas sensaçס̃es e, portanto, concebem as mesmas idéias; princípio ligado a este outro: que existe uma ordem natural segundo a qual as sensaçðes e as idéias se encadeiam, de maneira que se pode descobrir sua origem e reconstituir sua formação. A partir daí, poder-se-á dar conta de todas as diferenças: se há diversidade, é precisamente porque as condiçð̋es (e não somente as climáticas) não são idênticas, é porque variam as circunstâncias exteriores à natureza do homem. Variam tanto que podem degenerá-lo: "alimentação grosseira, malsã ou mal preparada pode fazer degenerar a espécie humana; todos os povos que vivem miseravelmente são feios e mal feitos; mesmo entre nós, a gente do campo é mais feia do que a das cidades, e notei freqüentemente que, nas povoaçðes onde a pobreza é menor que nas povoaçðes vizinhas, os homens são melhor feitos e os rostos menos feios".

Que a história do homem seja, no século XVIII, natural, não implica, portanto, apenas que ela rompe com a teologia (relembremos, no entanto, que ao descrever as Époques de la nature, sem fazer nenhuma referência aos tempos bíblicos, Buffon e seus colaboradores escreveram sem dúvida a primeira história física do mundo). Essa ruptura que, para além das polêmicas, constitui um dos marcos do século e um dos elementos de sua unidade, possui evidentemente conteúdos positivos. Se a Natureza é - para tomar ainda outra definição de Buffon - "o sistema de Leis estabelecidas pelo Criador, para a existência das coisas e para a sucessão dos seres", ${ }^{4}$ então, a história natural tem o projeto, e não somente o projeto como a possibilidade de descobrir a ordem necessária e sucessiva que, subjacente à multiplicidade observável, é capaz de explicá-la. Dois eixos são necessários para fornecer um tal modelo explicativo: geográfico (referente às condiçə̃es exteriores acidentais) e histórico (referente às leis naturais necessárias), mas o primeiro, como veremos, subordinado ao segundo.

(4) Sem entrar em pormenores, sublinhemos a novidade e a importância dessa definição. Ela visa, é claro, Descartes e sua teoria da criação contínua: se a succssão dos seres é sujeita a leis, imutáveis, e não a uma contínua intervenção divina, então uma ciência humana é possível. 
Em si mesma, a diversidade das sociedades é problemática, o que quer dizer que é preciso explicar racionalmente a distância que separa, digamos, os lapðes da sociedade policiada do século XVIII francês (com efeito, nem mesmo a hipótese de uma pluralidade originária das espécies no seio do gênero humano dá conta de uma tal distância); e, através dela, coloca-se o problema do progresso, o que quer dizer que é preciso reencontrar o caminho necessário da Natureza.

No pensamento da maior parte dos homens do século XVIII, todos os caracteres pelos quais os homens, e as sociedades, se diferenciam, estão estreitamente ligados; e mais: decorrem logicamente uns dos outros. Assim, à feiura física se conjuga a negritude moral, a estupidez, as crenças absurdas, os costumes cruéis, etc., e, inversamente, para as qualidades positivas (e este resumo não é uma caricatura: que se leia apenas as descriçð̃es que Buffon, Linneu, Voltaire, Raynal, De Pauw, fazem dos africanos, dos lapøes, dos chineses, dos índios da América). Além da diversão que proporciona ao leitor de hoje semelhantes retratos, há aí um pensamento que nos parece ser uma das peças-chave da antropologia de então: com efeito, não é ele que permite que se passe, quase sem dar-se conta, de um lado, do indivíduo para a sociedade e, de outro, da geografia para a história, isto é, das condiçð̃es externas para as çondiçðes internas? Ele também nos parece ter uma outra implicação: torna singularmente difícil a disjunção entre, de um lado, o discurso simplesmente científico (a descrição e a explicação dos costumes) e, de outro, o discurso moral e político (a sociedade descrita é boa ou má, e os homens são nela felizes?). Pois, certamente, não é por acaso que sempre encontramos, constantemente mesclados nos escritos dos téricos e dos etnógrafos, a observação dos costumes e sua avaliação moral. Voltaremos a este assunto. Mas, antes de mais nada, retomemos o primeiro ponto.

Este modo de pensar é, em suma, a aplicação ao estudo das sociedades, das teorias de Locke e de Condillac. Se as idéias provêm das sensaçðes, se as sensaçðes e as idéias se combinam segundo um pequeno número de leis numa ordem de complexidade crescente, então basta descobrir as causas das diferenças físicas (o primeiro e o mais simples dos dados, segundo as regras do método) para que todo o resto se explique. Essas causas, quase sempre, são exteriores, e a mais freqüentemente invocada é a do clima. A importância da teoria dos climas (controvertida, de certo) é conhecida; o que nos parece interessante é o tratamento que recebe, fora das teorias naturalistas, de Montesquieu, por exemplo, que a faz sua em L'esprit des lois. O clima (e também a alimentação, as doenças, etc.) explica, então, a distância 
que separa as sociedades atualmente observáveis sobre a terra: todas dotadas, na origem, de uma natureza idêntica (perfectível, não o esqueçamos) e portanto de possibilidades iguais, se viram localizadas em condiçðes reais completamente diferentes, algumas favoráveis à natureza, outras não; e, as mesmas causas continuando a agir e a acarretar os mesmos efeitos, a distância diferencial se amplificou progressivamente. Donde: aqui progresso, ali estagnação, alhures degeneração. E aqui estamos, como num passe de mágica, instalados na história, transportados das condiçðes acidentais para a ordem necessária. A geografia está aí apenas para atestar a existência de uma história (a história do homem) cujos diferentes momentos são representados pelas sociedades reais (selvagens ou antigas, pouco importa); a diversidade espacial ordena-se em decorrência, já que ela é legível como uma sucessão temporal mais fundamental; é levantada a questão da origem.

Aí está, com relação aos séculos precedentes, uma reviravolta completa que se opera na maneira de apreender as outras sociedades. Esses outros, bárbaros e selvagens, ${ }^{5}$ deixam a partir deste momento de ser concebidos como estrangeiros, como o eram, por exemplo, aos olhos dos homens do século XVI, para tornarem-se semelhantes: de mesma natureza que nós, e tais como éramos em nossos inícios. Primitivos. Que este novo modo de pensar os selvagens só tenha realmente tomado forma pelo movimento de idéias que acabamos de relembrar brevemente, poderemos confirmá-lo olhando para trás.

Aos primeiros exploradores do continente americano, os índios apareceram, antes de tudo, como pessoas de uma outra natureza que a deles mesmos. E, com efeito, o que viram eles? Selvagens que iam e vinham nus, sem sequer sonhar em esconder "o que no entanto natureza requer que se mantenha escondido"; mulheres que não possuíam nem um grama do pudor que "há naturalmente" neste sexo; crianças ignorando a obediência que a "natureza quer que se tenha" em relação aos mais velhos; e essas pessoas passavam o tempo a se entredevorar; e, ainda, se entregavam à sodomia, pecado "contra a natureza" por excelência, e que não queriam nem mesmo nomear. Nos etnografos do século XVI, esse vocabulário deve ser levado ao pé da letra: todos os traços de "cultura", diríamos nós, são para eles o indício de uma outra

(5) No século XVIII, as duas palavras são freqüentemente empregadas juntas para a mesma soçiedade. Elas não têm, no entanto, a mesma conotação, e a primeira é equívoca: ora "bárbaro" faz referência a um momento da história do homem, ora denota um conjunto de "qualidades" físicas e morais, notadamente a coragem e a crueldade. Selvagem é de um uso mais unívoco: sociedade onde os indivíduos são livres, onde não existe coerção religiosa nem política. 
natureza e, certamente, os selvagens não lhes são semelhantes. Por si só, essa maneira de descrever, no entanto tão particular aos relatos de então, pouco significaria. Mas, justamente, ela não está só e a história aí está para testemunhar o que foi pensado. E o fato é que os índios da América pareceram tão estrangeiros pelos seus hábitos (nunca pelo seu aspecto físico) que se perguntou seriamente, e durante várias décadas, precisamente sobre sua natureza: tinham eles ou não uma alma? Eram eles humanos? Questão abundantemente argumentada e controvertida e que não exigiu nada em menos, para ser concluída, que uma bula pontifícia - que não impediu, como se pode adivinhar, que se continuasse, durante um longo tempo, a debatê-la. (Além do que, o debate sobre os índios não foi concluído, ele apenas se transformou.) Tanto é que, ainda hoje, é possível o espanto: o que era necessário que fossem os selvagens para que, quando foram descobertos, nascesse tal controvérsia, com o que ela traduzia de certeza e de estupor; existem outras sociedades que tenham suscitado, dentro da nossa, questão assim fundamental? Aqui está, ao menos, mais do que é preciso para demonstrar que, aqueles que desde então denominamos os "selvagens", foram percebidos e concebidos como radicalmente outros, novos, singulares. Que se leia com um pouco de cuidado os cronistas da época: os índios lhes são tão inacreditáveis afinal, que, muitas vezes, antes de chegarem a descrever uma ou outra de suas particularidades, tomam mil precauçð̃es de estilo, certificando o fato de não estarem inventando nada, exagerando nada, enfim, que são verídicos. Sabemos, é claro, que, entre as testemunhas de então, há algumas que se contradizem: mas são raras e, quando se acusam mutuamente de mentira, é que suas interpretaçð̃es divergem; as informaçðes etnográficas, por sua vez, são perfeitamente concordantes (como no caso de Léry e de Thevet). Mas, se se teme tanto o descrédito, não seria na verdade porque esses selvagens são inverossímeis?

Entretanto, essa estranheza não exclui de forma alguma uma certa proximidade, e talvez mesmo possa torná-la possível. Essa proximidade é extremamente marcante, em todo caso, e manifesta-se de múltiplas maneiras. Pensando bem, não somente os indivíduos são próximos (se fizermos abstração das pinturas, tatuagens, orelhas e lábios perfurados, e outros procedimentos pelos quais os índios sabem tão bem se desfigurar, eles não são diferentes ou piores que os europeus; e suas qualidades, suas virtudes e seus vícios não são tão diversos), mas sobretudo sua sociedade ${ }^{6}$ esconde, sob a barbárie das manei-

(6) Pois é de sociedade que se fala nos séculos XVI e XVII. A questão de saber se o estado selvagem é ou não é um estado de sociedade ainda não se coloca. 
ras, uma certa ordem, uma certa justeza ou justiça. Estranhos pois à nossa natureza, nos são no entanto próximos; sua ordem social pode, moralmente, comparar-se à nossa: alguns fazem efetivamente a comparação (assim, Léry).

Os costumes permanecem irredutíveis, impermeáveis à compreensão. $\mathrm{Na}$ impossibilidade de compreendê-los, era ao menos possível descrevê-los, era um dever testemunhar: viajantes, missionários testemunharam. Dedicaram-se à descrição, tão minuciosa quanto possível, das singularidades observadas: como os selvagens caçam, pescam ou cultivam suas hortas; como preparam seus alimentos ou bebidas, e quem os prepara, e quando e como comem, bebem, dormem; e como nascem seus filhos, como se casam, como enterram seus mortos; quais são suas doenças e a maneira de curá-las; o jeito com que pintam o corpo, o escarificam, o enfeitam; e seus vilarejos, seus chefes, suas guerras e sua paz. Os índios suscitaram os grandes livros de etnografia.

$\widehat{E}$ esta dupla relação, ao mesmo tempo próxima e longínqua, do Ocidente com os selvagens, que o século XVIII vai derrubar. A nova ciência vai reaproximar, em princípio, os selvagens: não menos humanos que nós, e arrastados pela mesma história. Porém, situando-os na origem desta história, de fato ela os distancia infinitamente, abolindo, ao mesmo tempo, tudo que os diferencia.

$$
* * *
$$

Por sua vez, então, o século XVIII vai interessar-se pelo selvagem. E o interesse chega mesmo à paixão: não somente a filosofia se apodera dele para pensá-lo, mas ele tem seu lugar em todas as criações da literatura e da arte, no romance, no teatro, no balé e na própria música (Rameau compre uma “dança dos selvagens")... ele é adaptado, em suma, a todos os molhos. Jamais época alguma terá conhecido tal entusiasmo: ele é compreensível, sem dúvida, porque a época fez do selvagem um modelo (no sentido lógico e moral do termo). E preciso, está certo, estabelecer distinções no seio dessa proliferação do discurso sobre o selvagem. Mas, antes de tudo, quem são, nesta época, os selvagens? São ainda os índios da América (aos quais irão se juntar os tahitianos, mas somente no último terço do século, após a viagem de Bougainville): ${ }^{7}$ os do Brasil, que podiam ser vistos séculos

(7) Os povos do Mundo Antigo não são considerados selvagens. Os do Ārtico (lapð̌es, samoiedos) degeneraram; os habitantes de Berbérie, bárbaros, ao mesmo tempo refinados e cruéis; os povos da África Negra (então muito parcialmente e mal conhe- 
antes em Rouen e em Paris, e que existem apenas nos relatos antigos; os do Paraguai, com os quais os jesuítas ainda prosseguem na sua experiência de uma sociedade modelo (de que Voltaire caçoava tanto, e era admirada por Raynal); os do Canadá, sobretudo, que nos interessam de mais perto, já que, aliados aos huronianos, é que os franceses lá combatem os ingleses, aliados aos iroqueses. Os índios do $\mathrm{Ca}$ nadá são certamente aqueles aos quais nos referimos mais facilmente quando pensamos em "selvagens". De um lado, porque a realidade de sua sociedade deixa-se perfeitamente subsumir pelo conceito de selvageria (estado de insubordinação política, ausência de coerção religiosa, ignorância da propriedade privada); de outro lado, por serem os mais conhecidos nos meios esclarecidos, celebrizados pelo barão de $\mathrm{La}$ Hontan desde o começo do século. ${ }^{8}$

Eles interessam sob vários aspectos: continua-se a descrevê-los (e a veia etnográfica, longe de esgotar-se com o Renascimento, durou quase até o fim do século XVIII), a explicá-los também, a julgá-los enfim (veremos adiante se são ou não o objeto real dessas explicaç̃̃es e desses julgamentos); em todos os textos da época, o discurso científico e o discurso moral e político se repercutem constantemente. $\hat{E}$ que a ciência do homem, em relação à qual se é unânime em reconhecer como "a mais útil", não tem em si mesma o seu fim: sua finalidade é moral e política; trata-se de chegar, através do conhecimento das diversas sociedades, até aquela que coincidir finalmente com o reino da Razão, onde os indivíduos poderão realizar o fim que lhes foi atribuído pela Natureza, a saber, a felicidade. Explicação científica e juízo de valor estão, pois, intimamente associados, até mesmo nos teóricos da etnografia. Assim, Lafitau começa por anunciar que não está de forma alguma preocupado com o "conhecimento estéril" ou a "vã curiosidade": "deve-se", diz ele, "estudar os costumes apenas

cida), escravos e submissos a tiranos; os chineses, policiados sem dúvida alguma e há muito tempo, mas caídos num estado de estagnação... Van Gennep tem razão ao escrever: " "... a etnografia térica e, em seguida, a formação do método etnográfico, praticamente não foram influenciadas pelo orientalismo, pelo extremo-orientalismo nem pelo africanismo (...), mas antes pelo americanismo, e em dois casos (...) pelo oceanismo", op. cit., vol. 5, p. 100.

(8) Os textos de La Hontan - Voyages, Mémoires, Conversations - publicados em 1703 em La Haye, tiveram no mesmo ano três reimpressðes. Em 1704, essa edição é traduzida para o inglês, e La Hontan faz uma segunda edição, em francês, reimpressa duas vezes neste mesmo ano. Em 1705 aparece uma terceira edição que será reimpressa até em 1709. Duas outras ediçðes iriam seguir-se e o livro sairia sem interrupção até cerca de 1760. Enquanto isso, é traduzido para o holandês e para o alemão. Isto apenas para dar uma idéia do sucesso de uma obra hoje esquecida. 
para formar os costumes, e há sempre, em tudo, algo de que se pode tirar vantagem". ${ }^{9}$ Os costumes que se deve formar, criticar, não são apenas os dos selvagens (mesmo para o missionário que é Lafitau), são também (e para alguns filósofos são sobretudo) os nossos. Conseqüentemente, não basta mais descrevê-los nem espantar-se, é preciso compreender, e, para isso, comparar. Mas não qualquer coisa, nem de qualquer maneira. Não, por exemplo, os selvagens, ou os antigos, conosco; apenas o que é comparável, como, por exemplo, os antigos com os selvagens. Tal aproximação foi bem cedo realizada: já a encontramos em Fontenelle, que descobre "uma espantosa conformidade entre as fábulas dos americanos e as dos gregos", ${ }^{10}$ ou ainda no Padre Tournemine, que também teve o projeto de tratar da origem das fábulas e escreveu que "para julgar o que é verossímil, é preciso evitar julgá-lo em relação à nossa época... A verdadeira regra à qual devemos comparar as fábulas, são os costumes dos selvagens da América..." $\mathrm{O}$ fato é que o comparatismo, como método aplicado ao estudo dos costumes, se baseia num duplo postulado, a saber: há uma unidade do espírito humano que manifesta uma tradição comum original, e seu desenvolvimento histórico é sujeito a leis. É a projeção, ao plano da ciência dos costumes, das hipóteses do naturalismo, ou, mais que a projeção, sua seqüência lógica: não é verdade, com efeito, que a filosofia de Locke funda a passagem do fisiológico ao mental, e, além disso, não permite ela (à medida que considera que a sensação é primeira e o espírito tabula rasa) definir a unidade espiritual como identidade de conteúdo? (Percebe-se, é claro, que as coisas tendem a complicar-se singularmente, à medida que, com o encadeamento entre sensações e idéias, o espírito progride... mas voltaremos a isto mais adiante). Em todo caso, se a comparação torna-se possível como método (pois não se esperou o século XVIII para fazer comparações), é porque são postuladas uma unidade original de pensamento e, se tal é possível, uma unidade de tempo.

O livro de Lafitau abre-se com uma gravura, que o padre explica: "O frontispício representa uma pessoa na atitude de quem escreve, no momento empenhada em fazer a comparação entre diversos monumentos da antiguidade, pirâmides, obeliscos, figuras, panteðes, medalhas, autores antigos, e entre vários relatos, cartas, viagens e outras curiosidades da América, entre as quais está sentada. Dois gênios apro-

(9) Moeurs des Sauvages amériquains..., p. 5.

(10) Fontenelle, De l'origine des Fables.

(11) P. Tournemine, Mémoire de Trévous, nov.-déc. 1702. 
ximam esses monumentos uns dos outros, ajudando-a a fazer essa comparação, fazendo-a perceber a relação que podem ter entre si. Mas o tempo, a quem cabe dar conhecimento de todas as coisas e desvelá-las progressivamente, torna-lhe essa relação ainda mais sensível remetendo-a à fonte de tudo, e fazendo-a como que tocar com as mãos a conexão que todos esses monumentos têm com a primeira origem dos homens, com $o$ fundo de nossa religião..." 12 Em seguida, criticando os antigos relatos que chegaram a dizer dos selvagens que não possuíam costumes nem religião (o que de fato disseram, ao mesmo tempo que descreviam, e muito bem, crenças e costumes, como o nota o próprio Lafitau), Lafitau justifica sua própria empresa: "Trata-se apenas, pois, de provar essa unanimidade de sentimento em todas as Nações, mostrando que, efetivamente, não há nenhuma tão bárbara que não tenha uma religião e que não tenha costumes". Nessa unanimidade se enraiza a possibilidade de comparar: "Não somente os povos que chamamos de bárbaros têm uma religião, mas essa religião possui relaçð̃es de uma tal conformidade com a dos primeiros tempos, com o que chamavam, na antiguidade, de Orgias de Baco e da Mãe dos Deuses, os mistérios de Îsis e de Osíris, que se percebe de imediato, por esta semelhança, que se trata em toda parte dos mesmos princípios e do mesmo fundo".

A idéia de uma religião originária é banal no século XVIII. O que é preciso notar, é o lugar singular que ela ocupa no quadro "evolucionista" de então: com efeito, ao contrário do que ocorre com os costumes, as técnicas, as artes, as ciências, as leis e a arte de governar, que só progrediram (com, é claro, interrupçð̃es, decadências e renovaçชes), a religião só regrediu desde seu início. ${ }^{13}$ Originariamente, ela possuía um conteúdo racional: o sentimento e a idéia do Criador e da harmonia da criação (e pouco importa que se atribua este conteúdo à Natureza ou à Revelação, pois permanece o mesmo); pouco a pouco, ela foi se impregnando de toda uma miscelânea de superstiçðes absurdas e de ritos insensatos (como o atestam os ritos e mitos dos antigos gregos ou dos antigos egípcios) à medida que foi se distanciando de sua simplicidade e pureza originárias. "O gênero humano", escreve De

(12) Lafitau, Moeurs des Sauvages amériquains... O grifo é nosso.

(13) Diz Voltaire: "O tempo, ora corrompe os usos, ora os corrige... e a superstição, filha desnaturada da religiåo, distanciou-se da pureza de sua mãe, a ponto de forçar os homens a imolar seus próprios filhos". Essais sur les moeurs, Paris, 1829, p. 160. Nascida da natureza, a religiăo pôde desnaturar-se a ponto de engendrar ritos contra a natureza. 
Brosses, "havia de início recebido do próprio Deus instruçð̃es imediatas conformes à inteligência da qual sua bondade havia dotado os homens". ${ }^{14}$ Deus ou a Natureza, dependendo das opiniðes, no final dá no mesmo, já que a conclusão é idêntica: as religið̌es realmente observáveis, no passado como na atualidade, são todas degradadas, umas mais, outras menos, conforme os povos, em que se as observa, estejam mais ou menos distantes do seu começo. Daí (pelo menos em parte) as divergências de julgamento entre Lafitau e De Brosses, por exemplo, isto é, entre a religião dos americanos e a dos africanos. Lafitau, sob o véu de "magia" e de "idolatria" que começa a corrompêla, descobre sem maiores dificuldades esta religião original nos huronianos e nos iroqueses, em seu culto do Grande Espírito. Menos matizado, por escrever com um intuito deliberadamente contestatório, La Hontan localiza apenas esta religião originária, e pð̃e na boca de seu interlocutor huroniano: “Graças ao Grande Espírito que nos deu apenas a Luz natural, não apagamos este fanal, seguimos exatamente os Preceitos da Razão". ${ }^{15}$ É que os americanos, se não estão exatamente no início da história, ainda estão bem próximos dele e, portanto, não são muito pervertidos. Tal não é o caso dos africanos, instalados há muito tempo num "estado informe", tal que "seus costumes, suas idéias, seus raciocínios, suas práticas são as das crianças”. Todas as naçðes passaram, pois, por este estado (exceção feita, especifica De Brosses, à "raça escolhida"), apenas algumas abandonaram-no, de maneira que se quisermos compreender o que nelas era outrora praticado, basta ver o que ainda se faz nas que permaneceram neste estado, basta ver "este amontoado de práticas triviais de uma multidão de homens estúpidos e grosseiros" onde não se encontram sequer resquícios das "instruçðes imediatas conformes à inteligência" de que fora dotado na origem o gênero humano. Vê-se, em De Brosses, armarse um modelo explicativo que é histórico: explicar um fenômeno significa retornar às causas que o provocaram, às que o perpetuaram, desvelar o mecanismo pelo qual uma idéia de início inteligível (no caso a idéia da divindade) foi se obscurecendo pouco a pouco, deslocando-se até encarnar-se em objetos. Causas estas: "a ignorância associada ao temor" que caracterizam a infância dos povos (notemos, desde já, que há um elo perdido na história natural do homem: com efeito, como se passa racionalmente - sem recorrer à história

(14) De Brosses, Du Culte des Dieux fétiches...

(15) La Hontan, Conversations de l'Auteur avec un Sauvage distingué nommé Adario, Editions Elysées, Montreal, 1974. 
santa - do nascimento esclarecido à infância estúpida?). Ignorância e temor explicam, pois, que a divindade possa ter se identificado com personagens que a representavam, e depois com objetos utilizados por esses personagens, e, progressivamente, com qualquer tipo de objeto. $\mathrm{O}$ que perpetuou estas superstiçð̃es: o hábito, pois os usos não se desenraízam tão facilmente. Como prova o exemplo desse selvagem que tinha um boi por Manitu: "ele concordava em que não era este boi que ele adorava, mas um Manitu de boi que estava sob a terra e que animava todos os bois: ele concordava também que os que tinham um urso por Manitu adoravam semelhante Manitu de urso. Perguntaram-lhe se não havia também semelhante Manitu de homens; ele concordou. Mostraram-lhe então... que seria mais conveniente invocar o espírito que era senhor dos outros. Este raciocínio pareceu bom ao selvagem, mas não o fez mudar de hábito". ${ }^{16}$ A ignorância e o temor, a força do hábito, explicam, pois, o fetichismo; e a extensão que De Brosses dá ao termo, que acaba de inventar, permite-lhe explicar mais ou menos todos os ritos e todas as crenças, o xamanismo entre outros: tudo pode ser incluído nesta categoria. Tudo, ou quase: são excluídos as crenças e os ritos (próprios a "povos menos insensatos") centrados no sol e nos astros; estes constituem uma outra categoria, o sabeísmo. E De Brosses, para explicar a diversidade das religið̃es, chega a fabricar um modelo digno da botânica (a mais ordenada das ciências de então). Todos esses modos de pensar, diz ele, ao falar do que enquadra na categoria de fetichismo, "têm, no fundo, uma mesma fonte, ,... esta não é mais que o acessório de uma religião geral disseminada nos extremos de toda a terra, que deve ser examinada em separado, como classe particular dentre as diversas religiðes pagãs". A outra classe é o sabeísmo. Portanto, uma religião original justa, reta, que se subdivide, engendrando (como?) duas classes, fetichismo e sabeísmo, onde entra a totalidade das religiðes pagãs. $O$ modelo é uma classificação.

Todo modelo, decerto, depura e simplifica o real, mas o que este elimina, ao eliminar as singularidades, é a própria etnografia.

Embora procedendo diferentemente (quanto mais não seja por estudar uma sociedade particular e estudá-la na sua totalidade), Lafitau desemboca na mesma disjunção entre a etnografia e a teoria. Há nele o mesmo modelo "histórico", como o indica o discurso do método que inaugura seu livro: “... procurei manter um certo método, encadeando as coisas de tal modo que elas se encontram na ordem

(16) De Brosses, op. cit., p. 58-59. 
que devem naturalmente ter; e dando-lhes uma tal articulação que elas parecem derivar uma da outra... Na descrição dos costumes dos americanos, o paralelo com os antigos é sempre mantido, pois não há um único traço dos costumes daqueles que não tenha seu exemplo na antiguidade" (p. 18). E, de fato, seu paralelo se dá em todos os níveis: as crenças e os ritos, como vimos acima, mas também os costumes, desde que sejam distintivos (a couvade, por exemplo), pois dos costumes gerais "nada se pode concluir comparando-os" (Lafitau, seguramente, definiu muito bem o comparatismo), e ainda os objetos (a maraca, e o cistre de Îsis, p. 212), até o vocabulário (Areskui, nome que os huronianos dão ao Grande Espírito, e Ares, Marte dos povos da Trácia, p. 127). Ao contrário de De Brosses, ele cuida das singularidades. As coisas que encadeia segundo sua ordem natural, são os costumes americanos; aí se incrustam constantemente os paralelos com os antigos. Mas o que esse encadeamento e esse paralelo explicam? Os costumes dos selvagens? Dos antigos? A obra de Lafitau e a De Brosses são, sem dúvida alguma, obras de etnografia (encontram-se tanto numa como noutra, sobretudo na primeira, descrições bem precisas); elas se querem também, e o são, obras teóricas. Entretanto, acontece com a etnografia e a teoria o que acontece, em suma, com os selvagens e os antigos: existem paralelamente, mas nunca se encontram. Pois o que o novo método (o comparatismo) e o novo modelo (essa "história" natural e racional) não explicam, e nem podem fazê-lo, são exatamente os Selvagens. Aliás, o próprio Lafitau o entreviu: "confesso, diz ele, que se os autores antigos me forneceram evidências para apoiar algumas conjeturas felizes concernentes aos selvagens, os costumes dos selvagens me forneceram evidência para entender mais facilmente, e para explicar várias coisas que estão nos autores antigos" (p. 3-4).

Não seria que, tornados de direito primitivos, os selvagens são despojados de uma "história" anterior que possa, por sua vez, explicálos? De modo que o mesmo pensamento que (colocando os selvagens na espécie humana e inscrevendo o conjunto das sociedades na ordem de uma mesma história) funda o comparatismo, torna possível uma explicação científica dos costumes, e funciona, ao mesmo tempo, como obstáculo epistemológico para o conhecimento dos primitivos. ${ }^{17}$ Enquanto não é possível comparar os selvagens a eles mesmos, antes

(17) Morgan será o primeiro a explicar os costumes dos iroqueses (suas relaçðes de parentesco e de aliança) pelo estado passado e pela evolução desses mesmos costumes, sempre, portanto, segundo um modelo historico: foi necessário esperar, para atri- 
que aos gregos ou aos egípcios, a antropologia nada pode dizer deles. De modo que não é por acaso que o século XVIII ostentou tanto desprezo pelas "curiosidades" ou pelas "singularidades" das sociedades: com efeito, o que é que se poderia fazer com elas? Tomando-as em consideração, todo este conjunto teórico não teria podido funcionar. Os pensadores nada querem da etnografia (que eles, no entanto, conhecem), querem sim viajantes que sejam filósofos, que tragam idéias, e não "curiosidades". E quanto aos etnógrafos (quer obtenham suas observações da própria experiência, quer dos livros), eles descrevem fatos que é impossível explicar, já que não têm antecedentes. Ou melhor: não é necessário explicá-los. De um lado porque a ordem "natural", e conseqüentemente necessária, da descrição, faz as vezes de explicação. De outro lado, e sobretudo, porque as sociedades onde os observamos, estando ainda próximas do começo da história humana, estão também ainda próximas da natureza (não esqueçamos que a possibilidade da história está inscrita na natureza). Ora, por definição, a natureza - assim como o conjunto das leis que determinam a condição humana - tem em si mesma sua própria razão, e não há que explicá-la. Isto não quer absolutamente dizer que os costumes singulares dos selvagens provêm diretamente da natureza, longe disso: dela surgiram apenas as faculdades humanas, de perceber e conceber idéias, de experimentar sentimentos, pois há sentimentos naturais (também, mas voltaremos a isso mais tarde, a faculdade de tender à felicidade e, com este intuito, de se reunir em sociedade); o exercício dessas faculdades está sujeito a leis conhecidas, elas funcionam como uma combinatória que dá conta do progresso. Entre este belo ordenamento lógico e o pulular das singularidades reais, o abismo é intransponível: as singularidades só podem ser acidentais (senão elas não seriam exatamente singulares). Elas permanecem então (assim como no século anterior) inexplicáveis: mais vale ignorá-las e teorizar sobre aquilo que é possível compreender, por exemplo, o estado de natureza.

Uma ilusão de ciência que, por graça de uma ordem metódica, natural e racional ao mesmo tempo, permite descrever os fatos e não levá-los em conta. "Etnografia teórica", dizia Van Gennep, a respeito desses precursores do século XVIII: é propositalmente que conser-

buir aos primitivos a dimensão historica que lhes faltava, de um lado, que o naturalismo inventasse uma teoria transformista das espécies (com Darwin), e, de outro, que fosse criada uma nova ciência, a pré-história (com Boucher de Perthes e a descoberta do homem "antediluviano"). 
vamos sua expressão, por ela permitir distinguir suas obras da antiga etnografia e da etnologia futura, e por nela se encontrarem, mas totalmente desconexas, etnografia e teoria.

$$
* \quad * \quad *
$$

O melhor exemplo dessa disjunção entre a etnografia e o discurso teórico é, talvez, fornecido pela obra de La Hontan. Sabe-se que após uma longa estada no Canadá, o barão escreveu três volumes: dois dos quais - os Voyages e as Mémoires - descrevem, ao longo de suas aventuras, a geografia do Canadá, os costumes dos índios, as guerras. O terceiro (o que teve tanto sucesso) é uma crítica virulenta da sociedade européia (francesa, sobretudo), que se faz através de três conversas com um selvagem - sobre a religião, as leis, a moral - cujo objetivo confesso é de comparar os costumes franceses com os dos huronianos; e é também, formulada por este distinto huroniano (pois ele não raciocina, finge queixar-se La Hontan, do particular para o geral?), a teoria de então sobre a sociedade selvagem. $\hat{\mathrm{E}}$ notável que toda a realidade social dos huronianos (que La Hontan bem conhece e descreve noutro texto) seja abandonada: são apenas variaçð̌es sobre o Estado de Natureza, a Razão, o Direito natural. "Quer que eu te faça", pergunta Adario ao barão, "de acordo com a realidade, o quadro de uma sociedade de huronianos? São homens onde o Direito natural se encontra em toda a sua perfeição" (op. cit., p. 308). A noção de Direito natural tem, é claro, um conteúdo; nós o descobrimos ao longo dessas conversas de La Hontan. $\hat{\mathrm{E}}$ o direito cujo fundamento é o respeito da liberdade dos indivíduos. Idéia retomada pelos filósofos, como Diderot na Enciclopédia: "Nenhum homem recebeu da natureza o direito de comandar os outros. A liberdade é um presente do céu e cada indivíduo da mesma espécie tem o direito de gozá-lo tão logo goze da Razão"18 - o que implica, diga-se de passagem, que o direito positivo não decorre da natureza. "Tão logo goze da Razão": a restrição permite precisar o conteúdo deste direito que inclui, notadamente, a autoridade paterna (a única decorrente da natureza, a única também naturalmente limitada: ela termina quando as crianças chegam à autonomia, ao "état de se conduire", ibid.). Mas: o que é a liberdade individual? $\hat{\mathrm{E}}$ a possibilidade de realizar a tendência natural à felicidade. Assim, d'Holbach: "Ser livre é não encontrar nenhum obstáculo à nossa tendência para a felicidade";

(18) Encyclopédie. Artigo "Autoridade política". 
e mais: "Nenhum poder, sobre a terra, tem o direito de roubar ao homem a sua liberdade, que nada mais é do que a faculdade de trabalhar para sua felicidade". ${ }^{19}$ Assim, também, a Enciclopédia: “... todos os homens se reúnem no desejo de serem felizes. A natureza nos impôs a todos a lei de nossa própria felicidade", ${ }^{20}$ o que implica em que o objetivo da sociedade ("os homens se reúnem...") seja a felicidade dos indivíduos. Daí, serem indissociáveis, no pensamento do século XVIII, a análise teórica e o discurso moral e político. Cuida-se então de definir o que é o estado de natureza, e a questão é saber se tal estado é, ou não, aquele que permite a felicidade. Diderot escreve na sua Réfutation d'Helvetius: "Então é o estado selvagem preferível ao estado policiado? Eu o nego. Não basta mostrar-me que há mais crimes, seria necessário demonstrar-me que há menos felicidade".

Estado selvagem, estado de natureza. Este último termo possui mais de uma acepção. Indiquemos apenas que, além do sentido jurídico, há também uma conotação cronológica (a condição do homem na sua origem), e que ele se define, ainda, por oposição ao estado policiado (e, neste caso, será o estado no qual as técnicas, as artes e as ciências não prosperaram). Salvo raras exceçð̃es (notadamente Rousseau) esse termo é aplicado, em todos esses sentidos, aos selvagens reais: incontestavelmente representam o estado originário do homem - ou, pelo menos, estão muito próximos dele - não estão submetidos a uma autoridade política, ignoram as artes e as ciências. Mas, são ou não felizes?

O estado de natureza pode, portanto, ser definido: pode também ser aplicado a uma realidade, os selvagens, que, destarte, não carecem de explicação mais ampla - a natureza, como vimos, explica-se por si mesma. Se não há que explicar o estado de natureza, pode-se, em compensação, avaliá-lo: bom ou mau. No espaço deixado vazio pelo discurso científico vem insinuar-se o discurso moral 'e político: mas seu objeto real é a sociedade policiada, jamais a sociedade selvagem. As teorias concernentes ao bom selvagem, que tanto deram o que falar, têm apenas uma função crítica: La Hontan, a quem, no entanto, poder-se-ia imputá-las com mais razão, não se deixou enganar, como prova este diálogo pelo qual termina as Conversations:

"- La Hontan: Que terrível homem és, Adario! Teu humor errático te leva de um extremo a outro. Deves falar-me sobre a felici-

(19) D'Holbach, Système social, 1773, p. 145 e 107.

(20) Encyclopédie. Artigo "Felicidade". 
dade huroniana e, em vez disso, tu nos provocas e nos atacas mais do que nunca.

- Adario: O fato é que vós sois nossos verdadeiros antípodas quanto aos costumes, e não posso examinar nossa inocência sem refletir sobre vossa corrupção...".

* * * *

Retomemos, para terminar, exclusivamente o ponto de vistá da etnologia e de suas condiçðes de possibilidade: no que desemboca essa corrente de pensamento primitivista? Primitivismo, isto é, projeção, sobre as sociedades concretas, de um estado originário que não pode ser mais que um modelo logico ou, como tão bem viu Rousseau, que existe apenas por hipotese. Ele parece conduzir-nos a duas impossibilidades:' não pode explicar nem as sociedades primitivas, nem a seqüência da história.

Aparentemente, temos tudo para que a etnologia seja possível. Já foi definido seu objeto preferencial: os selvagens. Foram definidos seus métodos, e minuciosamente, já que definidos foram, não somente o comparatismo, mas também os métodos de observação e de investigação "de campo", na linguagem de hoje: a exterioridade exigida do observador, que não deve medir o que lhe é estranho a partir de suas próprias normas culturais (como diz La Hontan: “Quando examino as sociedades, não sou nem francês, nem huroniano”), a necessidade de aprender a língua dos povos que se quer estudar, e a de conviver com eles (como afirma Lafitau: “... não há que aventurar-se em pormenorizar os costumes e os hábitos de um país, caso não se lhe conheça a língua: ciência que requer um longo estudo, que muitos ignoram, mesmo quando crêem possuí-la..." (op. cit., p. 112)). Enfim, foi determinado o modelo segundo o qual deve-se explicar os fatos: a história. E é precisamente aí que isto não funciona: o modelo é tal que só pode deixar escapar seu objeto, num duplo erro de perspectiva. Perde seu objeto, como vimos, porque tal modelo não pode ser aplicado aos primitivos, justamente porque os primitivos não têm, por definição, história. Perde-o, também, porque é esse modelo que implica a eliminação da etnografia: por melhor que seja a etnografia, ela de nada serve; mais ainda, serve de obstáculo, já que o começo, postulado pelo modelo histórico, deve necessariamente ser simples. De modo que o método, por melhor definido que seja, será sempre inaplicável.

Não há melhor exemplo dessa eliminação da etnografia do que o primeiro questionário que resulta desse pensamento primitivista. 
Devemo-lo a De Gérando, membro da Sociedade dos Observadores do Homem. Aí podemos ler: "O homem, tal como a nós se mostra, nos indivíduos que nos cercam, encontra-se modificado simultaneamente por mil circunstâncias diversas, pela educação, pelo clima, pelas instituiçðes políticas, pelos costumes, pelas opiniðes estabelecidas, pelos efeitos da imitação, pela influência de necessidades artificiais que criou para si mesmo. No meio de tantas causas diversas, que se somam para produzir efeito tão grande e interessante, jamais poderemos discriminar a ação precisa de cada uma, se não encontrarmos termos de comparação que isolem o homem das circunstâncias particulares em que se nos apresenta, que o desnudem das formas acessórias ${ }^{21}$ sob as quais a arte escondeu, de nosso olhar, a obra da natureza". 22 Impossível maior clareza: "formas acessórias", eis no que se resume tudo que deriva da civilização, tudo o que faz uma cultura. Donde a vantagem de estudar os selvagens: sendo, entre eles, as "circunstâncias secundárias" incomparavelmente mais simples (se ousarmos dizê-lo), é fácil distinguí-las das "circunstâncias primeiras e fundamentais que pertencem ao proprio princípio da existência", as únicas que podem interessar à teoria. Pois é claro que o único objeto do estudo dos selvagens não são, obviamente, os próprios selvagens; o que se quer é "compor uma escala exata dos diversos graus de civilização, e... atribuir a cada um as propriedades que o caracterizam; permitindo reconhecer quais são as necessidades, as idéias, os hábitos que são produzidos a cada idade da sociedade humana". ${ }^{23} \mathrm{O}$ texto mereceria uma análise de todos seus passos, de tal modo é exemplar das aporias do primitivismo. Contentar-nos-emos em indicá-lo ao leitor e em fazer algumas observaçðes. Em primeiro lugar, não podemos deixar de pasmar diante da coexistência entre consideraçðes que julgamos ainda deveras pertinentes (são aquelas da atual etnologia) e afirmaçðes que a etnologia só poderia recusar. Como era de se esperar, as primeiras concernem às regras da boa etnografia (aprender a língua, demorar-se entre aqueles que se pretende estudar...) e a crítica das informaçð̃es contidas nos livros dos antigos viajantes: consideraçðes que mantêm perfeita continuidade com tudo que foi dito, desde o início do século, pelos etnógrafos téricos (quanto ao método etnográfico) e pelos filósofos (quanto à crítica dos textos), dando forma

(21) O grifoé nosso.

(22) De Gérando, Considérations sur les diverses méthodes à suivre dans l'observation des peuples sauvages, Paris, 1797.

(23) Ibidem. 
sistemática a essas duas tradiçð̃es. As afirmações da segunda categoria sistematizam igualmente o que foi dito, desde quase cem anos antes, no concernente à teoria: os costumes - no que têm de diverso e particular (precisamente o objeto da etnologia) - não passam de "circunstâncias acidentais", "secundárias", que é preciso tentar eliminar para compreender o homem.

Pois o objeto da ciência é o homem, e sua história (cf. citação acima). História da espécie que, a exemplo da natureza, deve ir do simples ao complexo, partir dos primitivos para chegar até nós, e que, querendo explicar a diversidade própria a esta espécie, deve, segundo a mesma lógica, partir da diversidade física, para chegar progressivamente à diversidade moral e social. A mesma combinatória que vale para a história geral, vale para as sociedades particulares, no caso, as dos selvagens. Mas como conciliar suas singularidades efetivas com a simplicidade que é a essência da primitividade? É preciso operar neles a mesma reconstrução: fazer, com relação a eles, uma espécie de "história" (de combinatória) local, que se encadeie na "história" geral.

Segue-se que, a despeito de seu título, o método a seguir para a "observação" dos povos selvagens é tudo, menos um método de observação. Ê antes um meio de experimentação: quanto à língua, será estudada indo do mais concreto ao mais abstrato, seguindo a ordem "a mais conforme à geração das idéias", e tendo sempre em mente que "as noçð̃es com que os selvagens devem estar menos ocupados, são as que pertencem à reflexão, e que remetem à moral e à.16gica", e interrogando-os antes de mais nada sobre as noçð̃es das idéias morais "que se ligam de mais perto às idéias sensíveis", etc. De forma idêntica para estudar o indivíduo: primeiro objetivo, "os sentidos do homem selvagem", suas sensaçðes, como elas se combinam, até tornarem-se idéias (que, como se sabe, provêm das sensaçðes), e descobrir-se-á assim "qual a extensão precisa da esfera de idéias que pertencem ao indivíduo selvagem, e os limites que a circunscrevem". $\hat{E}$ que o objetivo do viajante-filósofo, o objetivo de todo este método é "arrancar de algum modo ao selvagem o segredo de sua história intelectual, e de nos transmitir o diário da geração de suas idéias". ${ }^{24}$ Os selvagens, análogos perfeitos da estátua de Condillac (embora esta seja hipotética, e aqueles bem reais), serão "observados" como se fossem tabula rasa, isto é, serão reconstruídos segundo as regras do método condillaciano. Uma última observação a respeito destes "obser-

(24) O grifoé nosso. 
vadores do homem". Como o disse Van Gennep, eles efetivamente marcam um fim: mas não unicamente, nem essencialmente, por razðes de conjuntura (a interrupção do pensamento sob a Revolução e o Império). Sobretudo por eles serem o desenlace de um sistema de pensamento - o de Locke, retomado na França por Condillac - que, quanto à etnologia, só podia levar a um impasse, já que eliminava o próprio objeto da etnologia.

A ciência do homem do século XVIII não explica, portanto, os selvagens, por tê-los feitos primitivos. Também não explica, e pela mesma razão, a seqüência da história, isto é, as sociedades antigas: não dá conta delas de fato; e não pode fazê-lo, de direito. De fato, por não ser suficiente comparar os costumes dos selvagens aos dos antigos, para compreender estes últimos. A comparação tem a vantagem de generalizar: os costumes dos antigos (assim como os dos selvagens) não são mais únicos no gênero, já que se encontram, em outros lugares, semelhantes. Perdendo sua singularidade, tornam-se, em conseqüência, explicáveis, mas nada além disso: a comparação não tem, ela mesmo, valor explicativo. Mais sutil é o argumento de direito. Efetivamente, se vamos buscar a primitividade nos iroqueses, por exemplo, não é por acaso, e não é por conseqüência. Ê que não a encontramos nos antigos, pois estes fazem parte de uma história real, de um tempo histórico particular, o do ocidente, e se os chamamos "antigos", precisamente, é em referência a esta história (eles não estão como os selvagens no estado de natureza). Entre os primitivos e os gregos ou os egípcios, há uma ruptura, um vazio de história que nenhuma sociedade pode preencher, pois quando se vai dos primeiros para os segundos, passa-se de uma história universal abstrata - a historia do homem e da sociedade - para a história de uma civilização. Aí ainda a confusão entre o modelo e o real conduz a uma aporia. Pois, como preencher este vazio? É bem verdade que no século XVIII ele é tranqüilamente preenchido: apela-se para a história santa (indicamo-lo a respeito de De Brosses, mas ele não é nem por sombra o único).

Curiosamente, o que o século quis rejeitar torna-se necessário. Ora, se, para manter a historia das sociedades em pé, é preciso fazer um desvio pela teologia, é porque a noção de primitividade (que, no entanto, permitia integrar os selvagens na espécie humana, e, assim, torná-los acessíveis à ciência) opðe, ela própria, obstáculo à ciência. A natureza talvez não dê saltos. A ciência, sim, os dá sem percebê-lo, pois não é da natureza que se pode derivar a história. 